\title{
Long-eared Owl Asio otus breeding in a Caspian Gull Larus cachinnans colony: Reversed roles in protective nesting association?
}

\section{Hornugglor Asio otus häckande i en koloni med kaspiska trutar Larus cachinnans: Omvända skyddsroller för samhäckare?}

\author{
Klaudia Litwiniak (iD) \& Marcin Przymencki \\ Poleska 37/17, 51-354 Wrocław, Poland | kklitwiniak@gmail.com \& marcin.przymencki@wp.pl
}

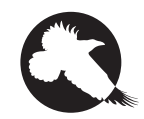

WE DESCRIBE the event of Long-eared Owls Asio otus nesting on an island within a colony of Caspian Gulls Larus cachinnans at the Mietków Reservoir (SW Poland). The owls nested in an old (possible corvid) nest in a willow and raised two owlets. They probably did not hunt gulls, neither adults nor chicks. We suggest that, in this case, the Long-eared Owls benefitted from breeding within a gull colony because of the added security against predators that the gulls provided.

Keywords: breeding association | breeding ecology | gull defense | nesting habitat | predator-free area

\section{Introduction}

The choice of a suitable habitat is presumably the result of integration of different habitat patches satisfying the different requirements of individuals (Orians \& Wittenberger 1991). Bird nest-sites must meet the fun- damental needs of breeding adults and young, including the protection from predators and weather, and also the proximity to food sources. Because a choice may enhance reproductive success, the behaviour involved 
in nest-site selection is thought to be adaptive (Collias \& Collias 1984). Furthermore, nest-site selection might be related to protective nesting associations. They relate specifically to those in which one or more associate species benefit directly from the protection provided by the other associate. The latter forms a protective umbrella around its own nest, thereby excluding mutual predators from the area (Quinn \& Ueta 2008).

The Long-eared Owl Asio otus is a relatively common typical owl of the family Strigidae, distributed over wide areas of North America, Europe, Middle East, and Asia (Snow \& Perrins 1998, Mebs \& Scherzinger 2000, Duncan 2003). Essential information on nesting habits of the Long-eared Owl has been collected in miscellaneous habitats, like deserts or agricultural landscapes in temperate areas (Rodríguez et al. 2006), and much is known about its breeding biology (Mikkola 1984, Cramp 1985, Tome 2007).

The Long-eared Owl usually lays its eggs in a large, old nest of another bird or in the drey of a squirrel Sciurus sp.; sometimes on the ground (Glue 1977). It also uses nest-boxes and nest-baskets. In Europe it most frequently uses nests of Eurasian Magpies Pica pica, Hooded Crows Corvus cornix, and Carrion Crows C. corone, but also nests of Rooks C. frugilegus, Northern Ravens C. corax, Eurasian Jays Garrulus glandarius, Common Wood Pigeons Columba palumbus, or Grey Herons Ardea cinerea (Glue 1977, Snow \& Perrins 1998, Purger \& Tepavcevic 1999; personal observations). Despite settling in many different habitats, tree species, and nests built by different species, we have not found any reports of Long-eared Owls nesting within gull colonies. Here we present the case of such nesting and discuss whether it could be regarded as protective nesting association.

\section{Material and methods}

While studying Caspian Gulls Larus cachinnans in their breeding colony in 2020, we found Long-eared Owls in a nest of unknown previous occupants. Due to its location, we decided not to visit the nest. During the following visits in the gull colony we tried to assess the breeding stage of the owls, using clues described in Seidensticker et al. (2006) and Hardey et al. (2013) to age the owlets. Determining the age of nestlings, we were able to estimate the date of clutch laying, as the incubat- ing period in this species is $25-30$ days (Glue 1977). On 11 May 2020 we collected 25 owl pellets under the nest and the adults' roosting site. The content of the pellets was analyzed by standard methods, following Marti (1974).

\section{STUDY SITE}

The gull colony is located on islands within the Mietków Reservoir, a $\sim 9.2 \mathrm{~km}^{2}$ dam reservoir in SW Poland (Litwiniak et al. 2020). Because of very low water level in 2020 , the area of the islands was larger than in previous years, but this year there were only 190 breeding pairs (in 2019 more than 260 pairs). The surface of the islands is mostly covered by grass and willows. In addition to gulls-Caspian, Yellow-legged Larus michahellis, Mew L. canus, Black-headed Chroicocepahlus ridibundus, and Mediterranean Gulls Ichthyaetus melanocephaluswe noted regularly breeding Mallards Anas platyrhynchos, Egyptian Geese Alopochen aegyptiaca, Greylag Geese Anser anser, Tufted Ducks Aythya fuligula, Mute Swans Cygnus olor, Common Terns Sterna hirundo, Common Wood Pigeons, Sand Martins Riparia riparia, and Eurasian Penduline Tits Remiz pendulinus. Owls had never been observed before to breed on islands at this site.

The population of Caspian Gulls at Mietków Reservoir was established in 1998 (Pola et al. 1998). In recent years the number of gull species and individuals breeding at Mietków Reservoir have been changing, e.g., Herring Gull Larus argentatus has previously bred there (Neubauer et al. 2006), but nowadays does not. There are usually eleven islands on which gulls might nest (their number depends on water level in reservoir). The breeding period usually starts at the end of March. In 2019 the first eggs were recorded on 29 March, in 2020 on 30 March. The peak of egg-laying was then observed 3-7 April (Przymencki 2020).

\section{Results}

On the morning of 24 April we observed a male Longeared Owl for the first time on the island. Later the same day later we found the old nest in a willow Salix sp., occupied by a female owl that probably incubated eggs (Figure 1). It was alarmed by our presence but did not leave the nest. The male was flying around the nesting tree and was being attacked by gulls. On 30 April 


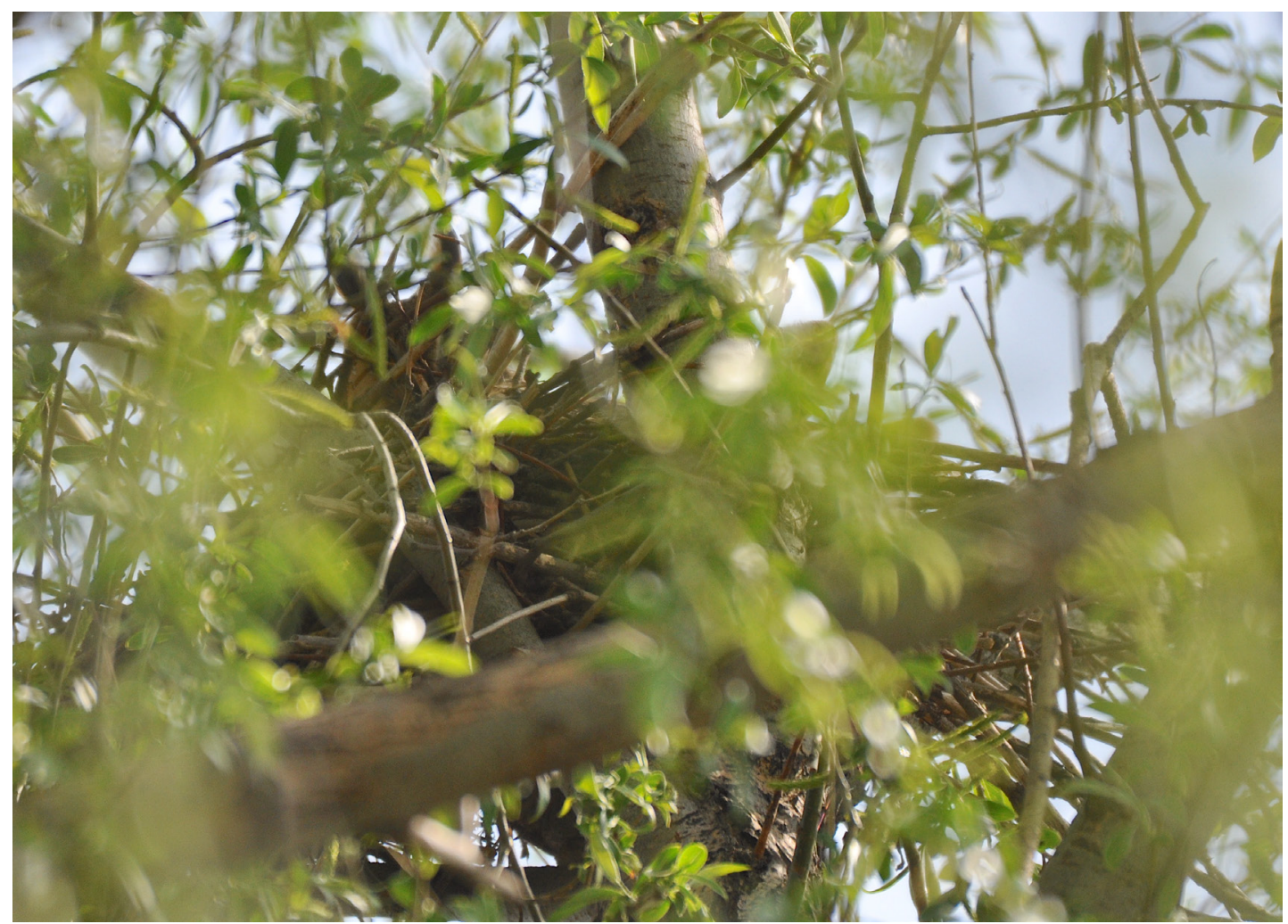

FIGURE 1. A female Long-eared Owl Asio otus on the nest in a willow Salix sp. within a Caspian Gull Larus cachinnans colony at the Mietków Reservoir, Poland, on 24 April 2020.

- En hornugglehona Asio otus på bo i en pil Salix sp. i en koloni av kaspiska trutar Larus cachinnans vid Mietków-reservoaren, Polen, 24 april 2020.

we did not observe any difference in breeding stage, but probably nestlings had already hatched. On 11 May we observed the male, the female, and for the first time one $\sim 10-14$-day-old owlet near the nest. On 22 May we found two owlets, estimated about 21-25 days old, sitting in a willow about 15-20 meters from the nest (Figure 2).

The Long-eared Owls had chosen to breed on one of the outermost islands with an area of 0.52 ha. The shortest distance from their nest to the mainland was $570 \mathrm{~m}$. The nest was located at $8 \mathrm{~m}$ height. On this island ten pairs of Caspian Gulls ( 8 to 65 on other islands), two pairs of Mallards and a pair of Common Wood Pigeon nested. Caspian Gulls started to lay eggs here on 2 or 3 April. We calculated that owls started to lay eggs on 29 March at the earliest.

In the owl pellets we found only bones and skulls of small rodents, mainly voles Microtus sp., with no remnants of gulls or other birds at all.

\section{Discussion}

Many authors have described situations where colonial birds nested close to owls. These were mainly wildfowl like Bean Geese Anser fabalis, Snow Geese A. caerulescens, Greater White-fronted Geese A. albifrons, Brent Geese Branta bernicla, or King Eiders Somateria spectabilis nesting in association with Snowy Owls Bubo scandiacus (Summers et al. 1994, Tremblay et al. 1997, Ebbinge \& Spaans 2002, Quinn et al. 2003, van Kleef et al. 2007, Kharitonov et al. 2009, Kharitonov et al. 2013). This phenomenon often occurs in years of high lemming abundance, when the number of arctic foxes Alopex lagopus is high (Tremblay et al. 1997; Kharitonov et al. 2013). Such association with raptors, that maintain a predator-free area around their nests, affects the quality of clutches and breeding success in wildfowl (Tremblay et al. 1997; van Kleef et al. 2007). It has also been shown that Ural Owls Strix uralensis can protect ground nests of birds (Halme et al. 2004). 


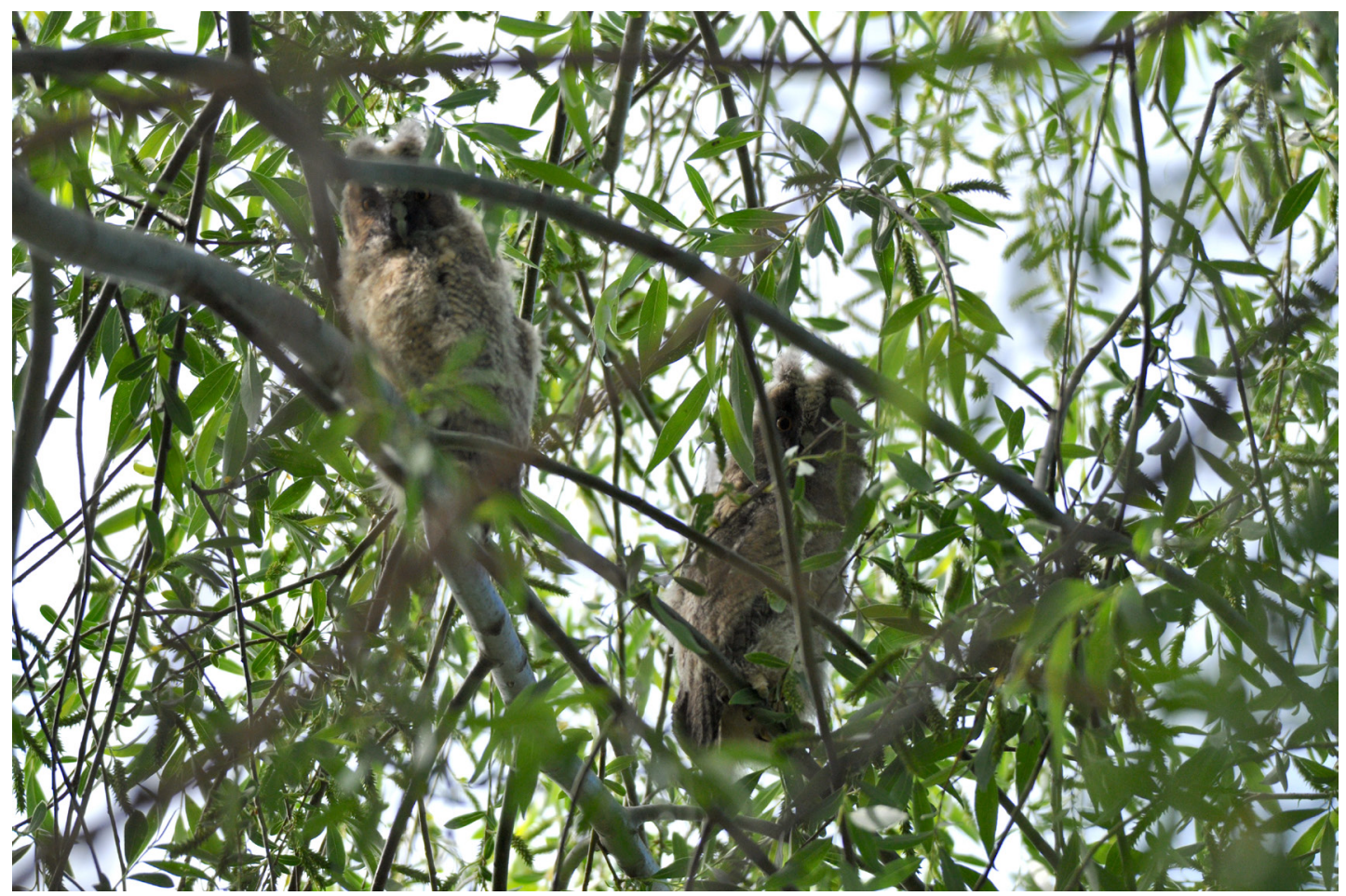

FIGURE 2. Two owlets of Long-eared Owl Asio otus, here in a willow Salix sp. on 22 May 2020, hatched within a Caspian Gull Larus cachinnans colony at the Mietków Reservoir, Poland.

- Två hornuggleungar Asio otus, här i en pil Salix sp. 22 maj 2020, kläckta i ett bo beläget inom en koloni av kaspiska trutar Larus cachinnans vid Mietków-reservoaren, Polen.

Ebbinge \& Spaans (2002) pointed out that Brent Geese nesting inside Herring Gull colonies are able to get some advantages. We argue that the case described in the present study reflects a similar situation, because the owls chose to nest within a breeding or nearbreeding gull colony. We found the first gull eggs on 30 March, but most likely eggs were laid even earlier in other parts of the colony. Thus, this Long-eared Owl pair settled at the edge of the existing (in this particular season) gull colony.

This pattern is opposite to that of the association between wildfowl and Snowy Owls. It is possible that here, the Long-eared Owls benefit from nesting within the Caspian Gull colony. Generally, coloniality reduces nest predation through communal mobbing of predators (Götmark \& Andersson 1984). Thus, the owls can reduce nest predation risk by exploiting the nest defense behavior of more aggressive species. Long-eared Owls are smaller and not as aggressive as Caspian Gulls, and may be indirectly protected by them. In our opinion such association may be adaptive and positively influence their fitness.

Breeding within a gull colony may have more advantages, for example it may serve as a potential food base. A few studies report Long-eared Owl and Short-eared Owl Asio flammeus predation on chicks of colonial birds, mainly Common Terns (Glue 1972, Becker et al. 1993, Holt 1994, Wendeln \& Becker 1999, Ludwig \& Becker 2008). We expected that the owls nesting within the gull colony would be hunting gull chicks, but we did not find any decapitated gull chicks inside the colony (cf. Glue 1972). Likewise, the analysis of pellets did not provide any evidence of such predation. One might also expect cases of predation on Common Terns nesting in the same area, but the terns only started to their egglaying at the time of fledging for the owlets.

Because of the absence of nocturnal predator defense mechanisms among breeding gulls (Southern \& Southern 1979), their chicks seem to be easy to capture. Many observations of owls hunting gulls have 
been done, among others Great Horned Owls Bubo virginianus hunting Ring-billed Gulls Larus delawarensis, California Gulls L. californicus, and Franklin's Gulls Leucophaeus pipixcan (Southern et al. 1982); Barn Owls Tyto alba and Short-eared Owls hunting Laughing Gulls Leucophaeus atricilla (Montevecchi 1977); and Snowy Owls hunting Ring-billed Gulls (Southern et al. 1982). However, in the present case no owl predation on Caspian Gulls was noted.

\section{Acknowledgements}

We wish to express our gratitude to the following persons who helped in various ways: Damian Celiński, Michał T. Jezierski, Paweł Grochowski, Romuald Mikusek, Grzegorz Neubauer, Joanna Pomorska-Grochowska, and Magdalena Zagalska-Neubauer.

\section{References}

Becker PH, Furness RW \& Henning D. 1993. Mercury dynamics in young Common Tern (Sterna hirundo) chicks from a polluted environment. Ecotoxicology 2: 33-40. https://doi.org/10.1007/ BFooo58212

Collias NE \& Collias EC. 1984. Nest Building and Bird Behavior. Princeton University Press, Princeton, NJ.

Cramp S. 1985. The Birds of the Western Palearctic. Volume IV. Terns to Woodpeckers. Oxford University Press, Oxford.

Tome D. 2007. Nest defense and some rare breeding events in Long-eared Owls (Asio otus). Journal of Raptor Research 41: 170-173. https://doi.org/10.3356/0892-1016(2007)41[170:NDASRB] 2.o.CO;2

Duncan JR. 2003. Owls of the world: their lives, behavior, and survival. Firefly Books, Buffalo, NY.

Ebbinge BS \& Spaans B. 2002. How do Brent Geese (Branta b. bernicla) cope with evil? Complex relationships between predators and prey. Journal of Ornithology 143: 33-42. https://doi.org/10.1007/ BFo2465456

Glue DE. 1972. Bird Prey taken by British Owls. Bird Study 19: 91-96. https://doi.org/10.1080/00063657209476330

Glue DE. 1977. Breeding biology of Long-eared Owls. British Birds 70: $318-331$.

Götmark F \& Andersson M. 1984. Colonial breeding reduces nest predation in the common gull (Larus canus). Animal Behaviour 32: 485-492. https://doi.org/10.1016/Sooo3-3472(84)80285-7

Halme P, Häkkilä M \& Koskela E. 2004. Do breeding Ural owls Strix uralensis protect ground nests of birds?: an experiment using dummy nests. Wildlife Biology 10: 145-148. https://doi.org/10.2981/ wlb.2004.019

Hardey J, Crick H, Wernham C, Riley H, Etheridge B \& Thompson D. 2013. Raptors: a field guide to survey and monitoring. 3rd edition. The Stationery Office, Edinburgh.

Holt DW. 1994. Effects of Short-Eared Owls on Common Tern Colony Desertion, Reproduction, and Mortality. Colonial Waterbirds 17: 1-6. https://doi.org/10.2307/1521375

Kharitonov SP, Ebbinge BS \& de Fouw J. 2013. Brent goose colonies near snowy owls: Internest distances in relation to breeding arctic fox densities. Biology Bulletin 40: 45-51. https://doi.org/10.1134/ S106235901301007X

Kharitonov SP, Nowak DJ, Nowak AI, Egorova NA, Korkina SA, Osipov DV \& Natalskaya OV. 2009. White-fronted and bean geese breeding near snowy owls, peregrine falcons, and rough-legged buzzards at the Taimyr Peninsula. Biology Bulletin 36: 643-646. https://doi.org/10.1134/S1062359009060168

van Kleef HH, Willems F, Volkov AE, Smeets JJHR, Nowak D \& Nowak A. 2007. Dark-bellied brent geese Branta b. bernicla breeding near snowy owl Nyctea scandiaca nests lay more and larger eggs. Journal of Avian Biology 38: 1-6. https://doi. org/10.1111/j.2007.0908-8857.03639.x

Litwiniak K, Przymencki M \& Celiński D. 2020. Short report on probable case of Caspian Gull predation on migrating swallows observed at first time. Ornis Hungarica 28: 181-184. https://doi. org/10.2478/orhu-2020-0012

Ludwig SC \& Becker PH. 20o8. Within-season divorce in Common Terns Sterna hirundo in a year of heavy predation. Journal of Ornithology 149: 655-658. https://doi.org/10.1007/s10336-008-0313-y

Marti CD. 1974. Feeding ecology of four sympatric owls. The Condor 76: 45-61. https://doi.org/10.2307/1365983

Mebs T \& Scherzinger W. 200o. Die Eulen Europas. Franckh-Kosmos Verlag, Stuttgart. [In German: The Owls of Europe]

Mikkola H. 1984. Owls of Europe. T and AD Poyser, Staffordshire.

Montevecchi W. 1977. Predation in a salt marsh Laughing Gull colony. The Auk 94: 583-585.

Orians GH \& Wittenberger JF. 1991. Spatial and temporal scales in habitat selection. The American Naturalist 137: 29-49. https://doi. org/10.1086/285138

Pola A, Rybarczyk R \& Stawarczyk T. 1998. Pierwsza kolonia lęgowa mewy srebrzystej Larus argentatus i mewy białogłowej Larus cachinnans na Śląsku. Ptaki Śląska 12: 158-16o. [In Polish: The first colony of the Herring Gull Larus argentatus and the Yellow-legged Gull Larus cachinnans in Silesia]

Przymencki M. 2020. Wybrane aspekty ekologii rozrodu mewy białogłowej Larus cachinnans na Zbiorniku Mietkowskim. MSc thesis, University of Wrocław. [In Polish: Selected aspects of breeding ecology of the Caspian Gull Larus cachinnans on the Mietków Reservoir]

Purger JJ \& Tepavčevic A. 1999. Pattern analysis of red-footed falcon (Falco vespertinus) nests in the rook (Corvus frugilegus) colony near Torda (Voivodina, Yugoslavia), using fuzzy correspondences and entropy. Ecological Modelling 117: 91-97. https://doi.org/10.1016/ So304-380o(99)00012-5

Quinn JL, Prop J, Kokorev Y \& Black JM. 2003. Predator protection or similar habitat selection in red-breasted goose nesting associations: extremes along a continuum. Animal Behavior 65: 297-307. https://doi.org/10.1006/anbe.2003.2063

Quinn JL \& Ueta M. 2008. Protective nesting associations in birds. Ibis 150: 146-167. https://doi.org/10.1111/j.1474-919X.2008.00823.x

Rodríguez A, García AM, Cervera F \& Palacios V. 20o6. Landscape and anti-predation determinants of nest-site selection, nest distribution and productivity in a Mediterranean population of Long-eared Owls Asio otus. Ibis 148: 133-145. https://doi. org/10.1111/j.1474-919X.2006.00492.x

Seidensticker MT, Flockhart DTT, Holt DW \& Gray K. 2006. Growth and plumage development of nestling Long-eared Owls. The Condor 108: 981-985. https://doi.org/10.1650/0010-5422(2006) 108[981:GAPDON] 2.0.CO;2

Snow DW \& Perrins CM. 1998. The Birds of the Western Palearctic. Concise edition. Volume 1. Non-passerines. Oxford University Press, Oxford. 
Southern LK \& Southern WE. 1979. Absence of Nocturnal Predator Defense Mechanisms in Breeding Gulls. Proceedings of the Colonial Waterbird Group 2: 157-162. https://doi.org/10.2307/1520949

Southern LK, Patton SR \& Southern WE. 1982. Nocturnal Predation on Larus Gulls. Colonial Waterbirds 5: 169-172. https://doi. org/10.2307/1521049

Summers RW, Underhill LG, Syroechkovski EE Jr, Lappo HG, PrysJones RP \& Karpov V. 1994. The breeding biology of Dark-bellied Brent Geese Branta b. bernicla and King Eiders Somateria spectabilis on the northeastern Taimyr Peninsula, especially in relations to Snowy Owl Nyctea scandiaca nests. Wildfowl 45: 110-118.

Tremblay J-P, Gauthier G, Lepage D \& Desrochers A. 1997. Factors Affecting Nesting Success in Greater Snow Geese: Effects of Habitat and Association with Snowy Owls. The Wilson Bulletin 109: 449-461.

Wendeln H \& Becker PH. 1999. Does Disturbance by Nocturnal Predators Affect Body Mass of Adult Common Terns? Waterbirds 22: 401-410. https://doi.org/10.2307/1522116

\section{Svensk sammanfattning}

Under studier av kaspiska trutar Larus cachinnans i en häckningskoloni i den $\sim 9.2 \mathrm{~km}^{2}$ stora Mietkówreservoaren i sydvästra Polen, upptäckte vi under häckningssäsongen 2020 ett par hornugglor Asio otus. De hade valt att häcka i ett gammalt fågelbo, troligen ursprungligen byggt av en kråkfågel, i en pil Salix sp. på en ö med tio par häckande kaspiska trutar.

På övriga öar i dammen häckade 8-65 par kaspiska trutar och utöver dessa fanns även häckande medelhavstrut Larus michahellis, fiskmås L. canus, skrattmås Chroicocepahlus ridibundus, svarthuvad mås Ichthyaetus melanocephalus, gräsand Anas platyrhynchos, nilgås Alopochen aegyptiaca, grågås Anser anser, vigg Aythya fuligula, knölsvan Cygnus olor, fisktärna Sterna hirundo, ringduva Columba palumbus, backsvala Riparia riparia och pungmes Remiz pendulinus. Ugglor har aldrig tidigare observerats häcka på öarna trots att den kaspiska trutkolonin studerats sedan 1998.

Vi upptäckte hornugglorna 24 april, då honan redan låg på boet och troligen ruvade ägg (figur 1 ). Vid nästa besök 30 april låg honan fortfarande på boet, men ungar kan redan ha kläckts eftersom vi elva dagar senare observerade en uggleunge som var 10-14 dagar gammal nära boet. Två ungar som bestämdes till 21-25 dagars ålder observerades i en pil 15-20 meter från boet 22 maj (figur 2). Utifrån dessa observationer och hornugglans tämligen välkända häckningsbiologi kunde vi beräkna att första ägget, som tidigast, bör ha lagts 29 mars. Vi hittade det första kaspiska trutägget på ön 30 mars, men trutarna kan ha startat äggläggningen något tidigare och fanns på plats en tid inför häckningen, således redan när hornugglorna startade sin häckning.

Flertalet tidigare studier har visat att kolonihäckande vattenfåglar ibland väljer att häcka nära häckande fjällugglor Bubo scandiacus, eftersom de sistnämnda håller stånd mot andra predatorer i reviret. Detta leder till högre häckningsframgång för kolonihäckarna. Samma mönster har funnits bland markhäckare som häckar nära slagugglebon Strix uralensis. På liknande sätt har prutgäss Branta bernicla påvisats åtnjuta fördelar av att häcka inne i gråtrutkolonier Larus argentatus. Således föreslår vi att hornugglorna i Mietków-reservoaren har kunnat dra fördelar av samma skydd, då kaspiska trutar är både större och mer aggressiva än ugglorna. Detta är, utifrån vår kännedom, första gången ett möjligt sådant samband noterats där ugglor åtnjuter skydd av, snarare än ger skydd åt, kolonihäckande fåglar.

Eftersom hornugglor kan jaga fåglar undersökte vi, genom att analysera 25 spybollar insamlade 11 maj, om ugglorna prederat trutungar i kolonin. Menyn bestod, emellertid, enbart av smågnagare och dominerades av sorkar Microtus sp.

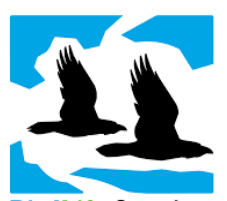

Birdlife Sverige

Ornis Svecica (ISSN 2003-2633) is an open access, peer-reviewed scientific journal published in English and Swedish by BirdLife Sweden. It covers all aspects of ornithology, and welcomes contributions from scientists as well as non-professional ornithologists. Accepted articles are published at no charge to the authors. Read papers or make a submission at os.birdlife.se.

Ornis Svecica (ISSN 2003-2633) är en fritt tillgänglig granskad vetenskaplig tidskrift som ges ut på svenska och engelska av BirdLife Sverige. Den täcker ornitologins alla områden och välkomnar bidrag från såväl forskare som icke-professionella ornitologer. Accepterade uppsatser publiceras utan kostnad för författarna. Läs uppsatser eller skicka in ditt bidrag på os.birdlife.se. 